\title{
Canine visceral leishmaniosis in an area of fishing tourism, Bonito Municipality, Mato Grosso do Sul, Central-West Brazil
}

\author{
Andreia Fernandes Brilhante ${ }^{{ }^{*}} \odot$ Maria Elizabeth Cavalheiros Dorval ${ }^{2}$ \\ Eunice Aparecida Bianchi Galati ${ }^{1}$ Vivianne de Oliveira Landgraf de Castro ${ }^{3}$ \\ Maria Elizabeth Ghizzi Rocca ${ }^{4}$ Gilberto Gonçalves Facco ${ }^{5}$ \\ Celeste da Silva Freitas de Souza $^{6}$ Vânia Lúcia Brandão Nunes ${ }^{5}$
}

\author{
${ }^{1}$ Faculdade de Saúde Pública, Universidade de São Paulo (USP), Av. Dr. Arnaldo, 715, 01246-904, São Paulo, SP, Brasil. E-mail: \\ brilhanteaf@usp.br. *Corresponding author. \\ ${ }^{2}$ Laboratório de Análises Clínicas (LAC), Universidade Federal de Mato Grosso do Sul (UFMS), Campo Grande, MS, Brasil. \\ ${ }^{3}$ Hospital Universitário Maria Aparecida Pedrossian (HUMAP/EBSERH), Campo Grande, MS, Brasil. \\ ${ }^{4}$ Núcleo de Controle de Zoonoses, Bonito, MS, Brasil. \\ ${ }^{5}$ Laboratório de Parasitologia Humana, Universidade Anhanguera, Campo Grande, MS, Brasil. \\ ${ }^{6}$ Laboratório de imunomodulação e protozoologia, Instituto Oswaldo Cruz, Rio de Janeiro, RJ, Brasil.
}

\begin{abstract}
The study aimed to investigate Leishmania infection in a population of dogs (92 animals) in a fishing area of Bonito Municipality, and evaluate comparatively the serological methods used, immunoenzymatic assay (ELISA), indirect immunofluorescence antibody test (IFAT), and rapid Dual Path-Platform test $\left(D P P^{\circledR}\right)$. Blood and aspirate of bone marrow samples were used and parasitological investigation was also performed, such as parasite isolation in Neal, Novy, Nicolle (NNN) medium culture, Woo technique, Giemsa stained smears and specific identification by polymerase chain reaction (PCR). IFAT revealed 56/92 seropositive, the ELISA 8/92 and the DPP ${ }^{\circledR} 41 / 92$. Regarding the agreement between the serological tests by the Kappa index, there was a slight agreement between ELISA/IFAT and ELISA/DPP ${ }^{\circledR}$, and fair agreement in IFAT/DPP ${ }^{\circledR}$. The NNN culture was positive in three out of 21 dogs, and identified by PCR as Leishmania infantum chagasi. No samples were positive by the Woo technique. Our results showed low agreements between the serological tests recommended by the Brazilian Ministry of Heath, and it is necessary to associate other diagnostic techniques, such as parasitological tests and PCR, to increase the sensitivity for canine visceral leishmaniosis diagnosis, mainly regarding asymptomatic dogs in endemic areas.
\end{abstract}

Key words: domestic dogs, serodiagnosis, ecotourism.

Leishmaniose visceral canina em área de turismo pesqueiro, município de Bonito, Mato Grosso do Sul, Centro-Oeste do Brasil.

RESUMO: O estudo teve como objetivo verificar a infecção por Leishmania em uma população de cães ( $n=92$ animais) de uma área de turismo de pesca no município de Bonito e avaliar comparativamente os métodos sorológicos utilizados, ensaio imunoenzimático (ELISA), reação de imunofluorescência indireta (RIFI) e teste rápido de plataforma dupla (DPP $\left.{ }^{\mathbb{}}\right)$. Testes parasitológicos também foram realizados, como o isolamento do parasita em meio de cultura Neal, Novy, Nicolle, técnica de Woo, esfregaços em lâminas coradas com Giemsa e identificação especifica pela reação em cadeia da polimerase (PCR). A RIFI revelou sorologia positiva de 56/92, ELISA 8/92 e DPP ${ }^{\circledR} 41 / 92$. Quanto à concordância entre os testes sorológicos pelo índice Kappa, houve um ligeiro acordo entre ELISA/RIFI e ELISA/DPP ${ }^{\circledR}$, e uma concordância razoável entre RIFI/DPP ${ }^{\circledR}$. A cultura NNN foi positiva em três cães, e identificada por PCR como Leishmania infantum chagasi. Nenhuma amostra foi positiva pela técnica de Woo. Nossos resultados mostraram baixas concordâncias entre os testes sorológicos recomendados pelo Ministério da Saúde, sendo necessário associar a outras técnicas de diagnóstico, como testes parasitológicos e PCR, para aumentar a sensibilidade ao diagnóstico de leishmaniose visceral canina, principalmente, com relação aos cães assintomáticos em áreas endêmicas. Palavras-chave: cães domésticos, sorodiagnóstico, ecoturismo.

\section{INTRODUCTION}

In Brazil, visceral leishmaniasis (VL) is a zoonosis of public health importance, and its etiological agent is Leishmania (Leishmania) infantum chagasi. As main vectors of this parasite, two phlebotomine sandfly species, Lutzomyia longipalpis, widespread in the country, and Lutzomyia cruzi registered in Mato Grosso do Sul and Mato Grosso States, (SANTOS et al., 1998; LAINSON \& SHAW, 2005; MISSAWA et al., 2011; BRASIL, 2014) have been implicated, and the domestic dog has been considered the common reservoir, with 
canine cases normally preceding the occurrence of human cases (GONTIJO \& MELO, 2004).

The first cases of canine and human visceral leishmaniasis in Mato Grosso do Sul date back to the 80 s at the Corumbá municipality (NUNES et al., 1988; YAMAMOTO et al., 1988). By the 90s, the visceral leishmaniasis spread widely across the state being diagnosed in 56 of its 78 municipalities, affecting rural and urban populations of different age groups and the vectors have being reported in almost all the municipalities (CORTADA et al., 2004; OLIVEIRA et al., 2006; NUNES et al., 2008; LIMAJÚNIOR et al., 2009; ANDRADE et al., 2009; MATO GROSSO DO SUL, 2014).

Researches undertaken in Bonito District have reported natural infection by Leishmania in sandflies and dogs in both rural and urban areas (NUNES et al., 2001; 2008; GALATI et al., 2006; SAVANI et al., 2009, ANDRADE et al., 2009; BRILHANTE et al., 2015b), and a moderate incidence of the disease in both human and canine populations (ANDRADE et al., 2009; MATO GROSSO DO SUL, 2014).

According to the Brazilian Ministry of Health, serological methods are used to diagnose and control programs of canine visceral leishmaniasis (CVL) in the country (BRASIL, 2014). However, the complexity of the diagnosis of CVL should be considered due to the low sensitivity of the tests, variance of clinical signs, presence of asymptomatic dogs and social factors caused by the culling of dogs (DE SANTIS et al., 2013).

In Águas do Miranda District, one of the major tourist resorts for ecotourism and sporting fishing in midwestern Brazil, the notification of CVL led us to investigate the infection by Leishmania in the canine population, and compare the performance of serological methods used, whose results are reported in this study.

\section{MATERIALS AND METHODS}

\section{Study area}

Bonito Municipality, one of the Mato Grosso do Sul municipalities, is situated in the southwest of Mato Grosso do Sul in the geomorphological unit known as Bodoquena Plateau, and consists of two districts: Bonito, containing the municipal offices, and Águas do Miranda, both considered important regional, national and international tourist resorts (IBGE 2016; BONITO, 2016).

The District of Águas do Miranda (20 45'44.4” S, 56 $\left.05^{\circ} 42.8^{\prime \prime} \mathrm{W}\right)$ is $75 \mathrm{~km}$ from the Municipality of Bonito District containing the municipal offices ( $\left.21^{\circ} 07^{\prime} 16^{\prime \prime} \mathrm{S}, 56^{\circ} 28^{\prime} 55^{\prime \prime} \mathrm{W}\right)$, and $180 \mathrm{~km}$ from Campo Grande, the capital of the Mato Grosso do Sul State (IBGE, 2016) (Figure 1). The human population consists of 450 inhabitants, which may rise to as many as 10,000 in the fishing season, from March to October. The local economy is based mainly on fishing and ecotourism (BONITO, 2009).

\section{Sampling}

With information about the occurrence of CVL cases and the help of the Zoonosis Control Center of Bonito Municipality, domiciliary visits were made in the Águas do Miranda District from June to December 2009. By consent of the owners, the 92 adult dogs, which constituted the local canine population, were submitted to clinical evaluation for the identification of manifestations suggestive of leishmaniosis. About $5 \mathrm{ml}$ of venous blood was collected by jugular or cephalic vein puncture and stored in plastic tubes without and with anticoagulant (ethylenediaminetetraacetic acid - EDTA). Serum samples were stored at $-20^{\circ} \mathrm{C}$ until the performance of the serological techniques.

For the 41 positive dogs in the Dual PathPlatform test $\left(\mathrm{DPP}^{\circledR}\right)$, a second visit was made to their owner's domicile to collect bone marrow blood samples. However, only for 21 of the dogs it was possible to obtain samples.

\section{Serological tests}

Serum samples were used for serological tests which were carried out in the laboratory of Imunodulação e Protozoologia of the Oswaldo Cruz Institute/FIOCRUZ in Rio de Janeiro. The techniques used for the diagnosis of CVL were indirect fluorescent antibody test (IFAT) (kit IFI Canine Visceral Leishmaniosis Bio-Manguinhos/FIOCRUZ); enzyme-linked immunosorbent assay (kit ELISA Canine Visceral Leishmaniosis Biomaguinhos/FIOCRUZ), and immunochromatographic rapid test (kit TR DPP ${ }^{\circledR}$ Canine Visceral Leishmaniosis-Bio-Manguinhos/ FIOCRUZ). The latter is a lateral flow test for the detection of antibodies specific for Leishmania, using recombinant proteins K26 and K39 specific for Leishmania infantum chagasi. Serological techniques and immunochromatographic assay were performed according to the manufacturer's instructions. In order, to classify the positive results, the following criteria were considered: IFAT titres equal to or higher than 1:40, ELISA readings over the cut-off, and for $\mathrm{DPP}^{\circledR}$, the emergence of two lines 15 minutes after buffer placement. 


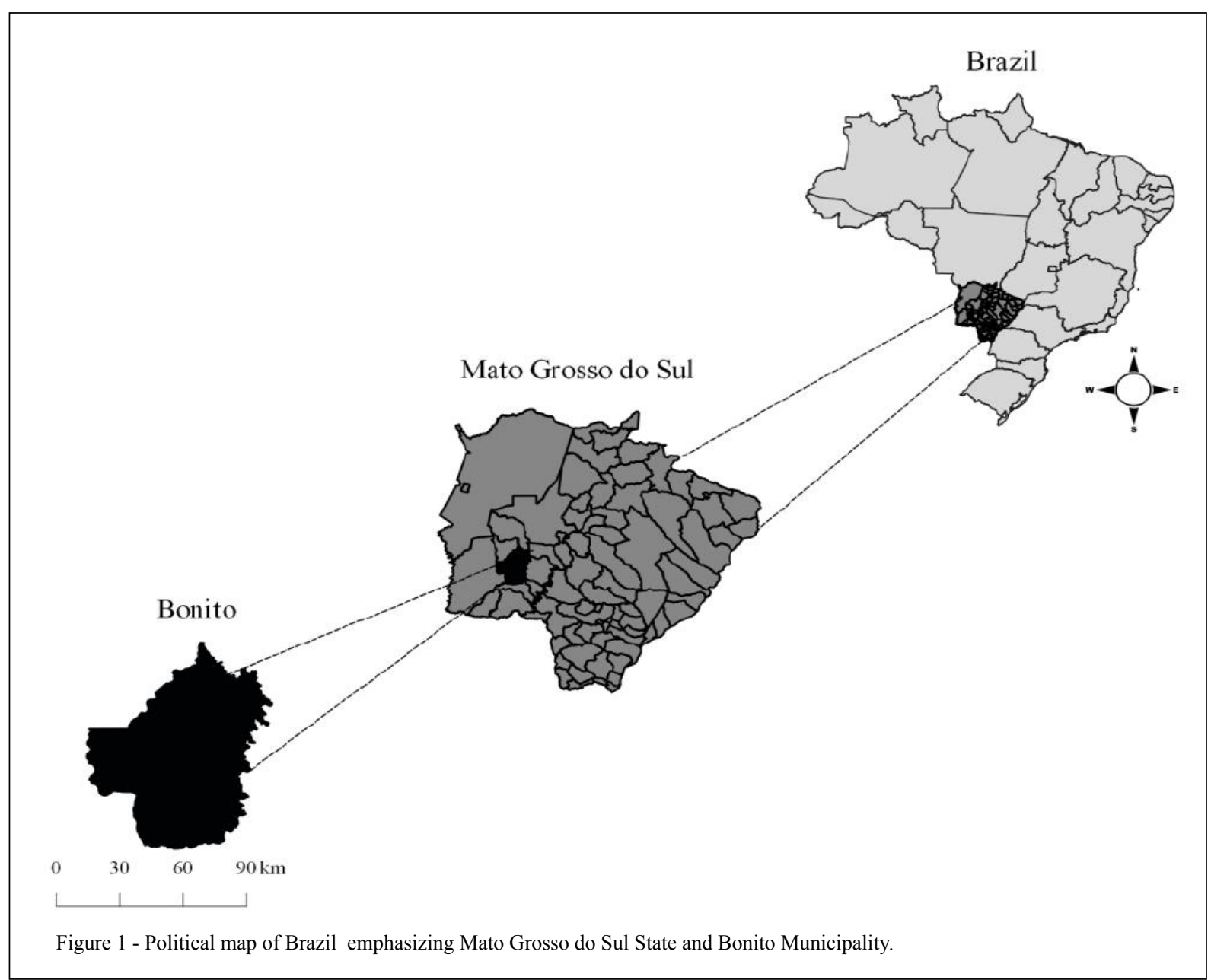

\section{Parasitological diagnosis}

The Woo technique was applied to identify trypanosomatid flagellates from total blood samples in accordance with WOO (1969). The method consisted of filling two capillary tubes with approximately 0.06 $\mathrm{ml}$ of peripheral blood, which were flamed sealed at one end and centrifuged at 12,000 rpm (Make of centrifuge) for 4 minutes. These tubes were then placed in a capillary tube holder and examined under a microscope using a $10 \mathrm{X}$ objective to investigate trypanosomes at the junction of the plasma and buffy layer in the centrifuged blood (WOO, 1969).

For observation of amastigote forms, part of the bone marrow blood sample was used to prepare Giemsa stained smears $(n=21)$. The remainder of each sample was inoculated intraperitoneally into two hamsters (Mesocricetus auratus) $(\mathrm{n}=42)$. Nine months after inoculation, the hamsters were necropsied and fragments of their liver and spleen were seeded in NNN culture medium supplemented with $20 \%$ fetal bovine serum. Samples were seeded in duplicate, with a total of 84 cultures.

\section{DNA extraction and molecular test}

Positive samples of the NNN culture had their DNA extracted using a DNAzol ${ }^{\circledR}$ kit in accordance with the manufacturer's instructions, and then analyzed by polymerase chain reaction (PCR) for the Leishmania infantum chagasi using the initiators RV1- CTTTTCTGGTCCCGCGGGTAGG e RV2- CACCTGGCCTATTTTACACCA. The PCR conditions were undertaken according to LIMAJÚNIOR et al. (2009). The DNA reference strain was $L$. infantum chagasi (MHOM/BR/74/PP/75), supplied by the laboratory of Leishmaniasis of the René Rachou Research Center (Belo Horizonte, Brazil). 


\section{Statistical analysis}

To evaluate the agreement between serological techniques (ELISA, IFAT and DPP ${ }^{\circledR}$ ), the Kappa coefficient $(\kappa)$ was calculated with confidence interval of $95 \%$. The test was performed by software Bioestat version 5.3 (AYRES et al., 2007). Values of $\kappa$ were considered according to SOLANO-GALLEGO et al. (2014) as: no agreement $(\kappa<0)$, slight agreement $(0<\kappa<0.2)$, fair agreement $(0.2<\kappa<0.4)$, moderate agreement $(0.4<\kappa$ $<0.6)$, substantial agreement $(0.6<\kappa<0.8)$ and almost perfect agreement $(\kappa>0.8)$.

\section{RESULTS}

The total number and percentages of positive animals in serological tests and parasitological examination according to clinical symptomatic or asymptomatic status are shown in table 1 . The IFAT revealed 56/92 seropositive, the ELISA 8/92, and the $\mathrm{DPP}^{\circledR} 41 / 92$. Regarding the agreement between the serological tests by the Kappa index, there was a slight agreement between ELISA/IFAT and ELISA/ DPP, and fair agreement in IFAT/DPP (Table 2).

Amastigote forms were observed in the Giemsa stained smears of the bone marrow from three dogs $(3 / 21)$. Promastigote forms were also observed in three cultures seeded with the spleen and/or liver fragments of the inoculated hamsters. Flagellates from the positive cultures samples were identified by PCR as Leishmania infantum chagasi. It is noteworthy that three dogs (3/92) were positive in all tests performed. No flagellates were observed in the peripheral blood by Woo's technique. The photograph of imprint smear from bone marrow of a positive dog demonstrating the amastigote forms and the electrophoresis in agarose gel are available in this research as supplementary material (Figure 2; Figure 3).

In the canine survey, five (5.4\%) dogs showed clinical signs suggestive of CVL, such as weight loss, alopecia and onychogryphosis, and were positive in all serological tests, while 87 (94.6\%) were asymptomatic. In other words, they did not present any of the symptoms described above. Of the 87 asymptomatic dogs investigated, $36(41.4 \%)$ were positive in at least one of the diagnostic tests performed.

\section{DISCUSSION}

In Mato Grosso do Sul, a large number of seropositive asymptomatic dogs have been reported, both in rural settlements and urban areas of Bonito District (NUNES et al., 2001; ANDRADE et al., 2009) in Anastácio, a municipality adjacent to Bonito (CORTADA et al., 2004) and Campo Grande (MATO GROSSO DO SUL, 2014). Similar results were reported in Mato Grosso State(MATO GROSSO DO SUL, 2014; DE SANTIS et al., 2013) and other areas in the Brazilian south-eastern and north-eastern regions (DANTAS-TORRES et al., 2006; COURA-VITAL et al., 2011). Some studies suggested that animals without apparent clinical signs of CVL could be the source of Leishmania for phlebotomine sandflies (MORENO \& ALVAR, 2002; LAURENTI et al., 2013); although, VERÇOSA et al. (2008) have demonstrated that asymptomatic dogs are not efficient sources of Leishmania for vectors.

Low agreement between the serological tests in our study can also be observed in researches carried out in Monte Negro - Rondônia (RO) State (AGUIAR et al., 2010), between ELISA and IFAT test, in Panorama - São Paulo (SP) State (LOPES et al., 2017), between ELISA and DPP tests. However, also high and moderate agreements have already been observed between the ELISA and IFAT tests in other localities of Brazil, as in Campo do Goycatazes - Rio de Janeiro State (TÁVORA et al., 2007) and Ilha Solteira (SP) (ASSIS et al., 2010; QUEIROZ et al., 2010). These observations demonstrated the need to better assess the diagnostic techniques of CVL, aiming at standardization, considering the evolution of the disease in the dog and its immune response.

Table 1 - Number and percentage of positive dogs in serological techniques for Leishmania by clinical status, Águas do Miranda District, Bonito, Mato Grosso do Sul, Brazil, 2009.

\begin{tabular}{lcccccccc}
\hline \multirow{2}{*}{ Clinical status } & \multicolumn{2}{c}{ ELISA } & \multicolumn{2}{c}{ IFAT } & \multicolumn{2}{c}{ DPP $^{\circledR}$} & \multicolumn{2}{c}{ ELISA, IFAT and DPP $^{\circledR}$} \\
\hline & $\mathrm{n}$ & $\%$ & $\mathrm{n}$ & $\%$ & $\mathrm{n}$ & $\%$ & $\mathrm{n}$ & $\%$ \\
Asymptomatic $(\mathrm{n}=87)$ & 3 & 37.5 & 51 & 91.0 & 36 & 87.8 & 2 & 28.6 \\
Symptomatic $(\mathrm{n}=5)$ & 5 & 62.5 & 5 & 9.0 & 5 & 12.2 & 5 & 71.4 \\
Total $(\mathrm{n}=92)$ & 8 & 8.7 & 56 & 60.8 & 41 & 44.5 & 7 & 7.6 \\
\hline
\end{tabular}

ELISA: enzyme-linked immunosorbent assay; IFAT: indirect immunofluorescence antibody test; DPP $^{\circledR}$ : Dual Path-Platform test. 
Table 2 - Agreement analysis by Kappa index between serological techniques (ELISA/IFAT, ELISA/DPP and IFAT/DPP) for diagnosis of canine visceral leishmaniosis (CVL) in domestic dogs, Águas do Miranda, Bonito, Mato Grosso do Sul, Brazil.

\begin{tabular}{lcccccccccccc}
\hline $\begin{array}{l}\text { Comparison } \\
\text { between tests }\end{array}$ & $+/+$ & $+/-$ & $-/+$ & $-/-$ & Total & $\kappa$ & CI & Agreement \\
\hline ELISA/IFAT & 8 & 0 & 48 & 36 & 92 & $0.115^{*}$ & $-0.214-0.445$ & 0.008 & Slight \\
ELISA/DPP & 7 & 1 & 34 & 50 & 92 & $0.164^{*}$ & $-0.135-0.464$ & 0.005 & Slight \\
IFAT/DPP & 34 & 22 & 7 & 29 & 92 & $0.384^{*}$ & $0.190-0.578$ & $<0.001$ & Fair \\
\hline
\end{tabular}

+: Positive; -: Negative; * Statistically significant $(\mathrm{P} \leq 0.05)$, confidence interval $95 \%$. ELISA: enzyme-linked immunosorbent assay; IFAT: indirect immunofluorescence antibody test; DPP ${ }^{\circledR}$ : Dual Path-Platform test.

In this research, the use of molecular tools was only possible in positive samples of NNN cultures. Previous studies have shown that the combination of serological and molecular techniques increase the detection of the parasite in the canine population, indicating failures in the official protocol of diagnosis of CVL in Brazil (QUEIROZ et al., 2010; LOPES et al., 2017). However, molecular tests are not available in all laboratories in the public system, and there is still no gold standard for the diagnosis of CVL, since for this technique there is the application of different protocols.

Until the year 2011, the ELISA and IFAT are methods recommended by the Brazilian Health Ministry (BHM) for CVL diagnosis. The ELISA was employed for screening large populations, and

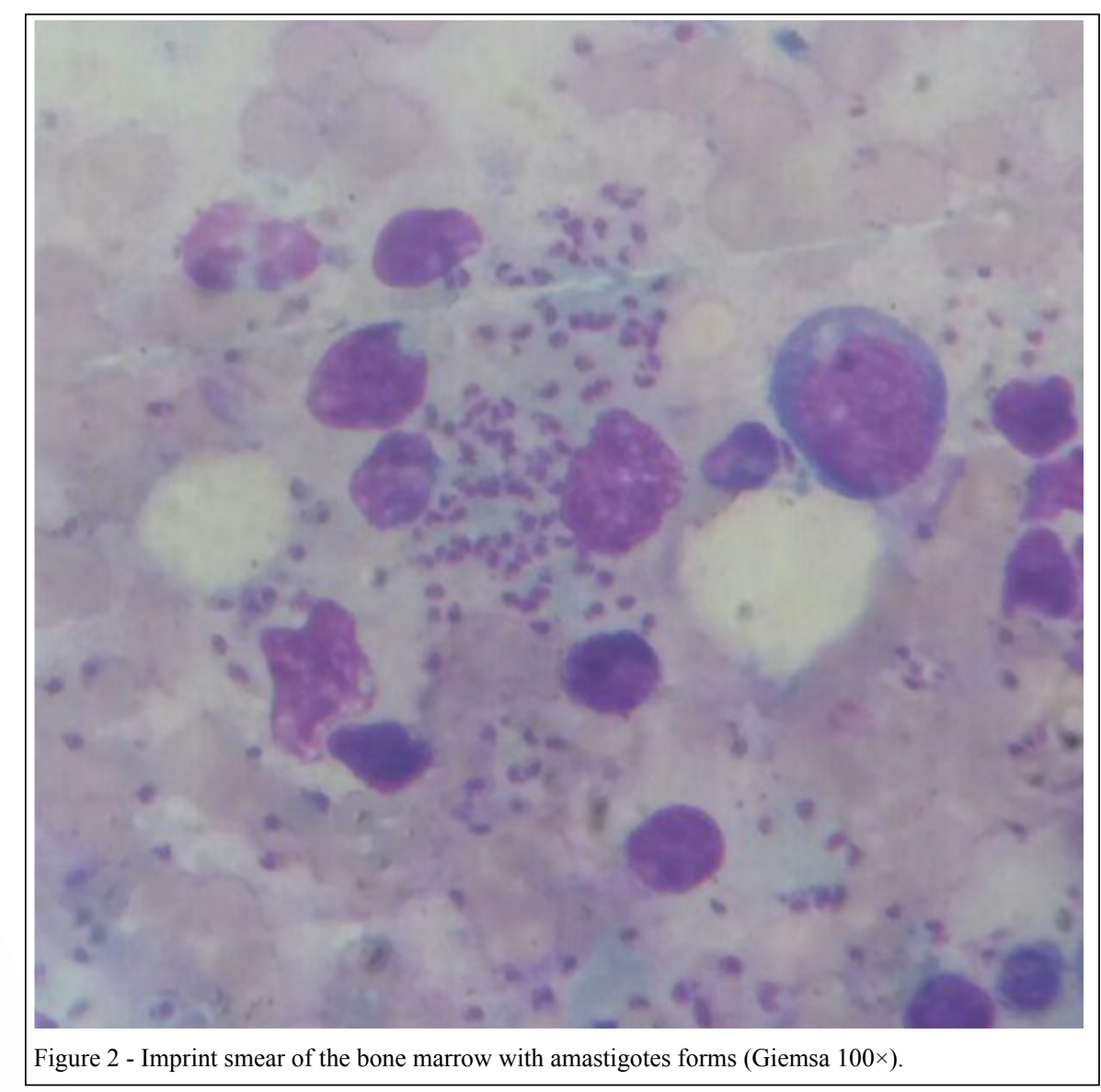

Ciência Rural, v.48, n.3, 2018. 


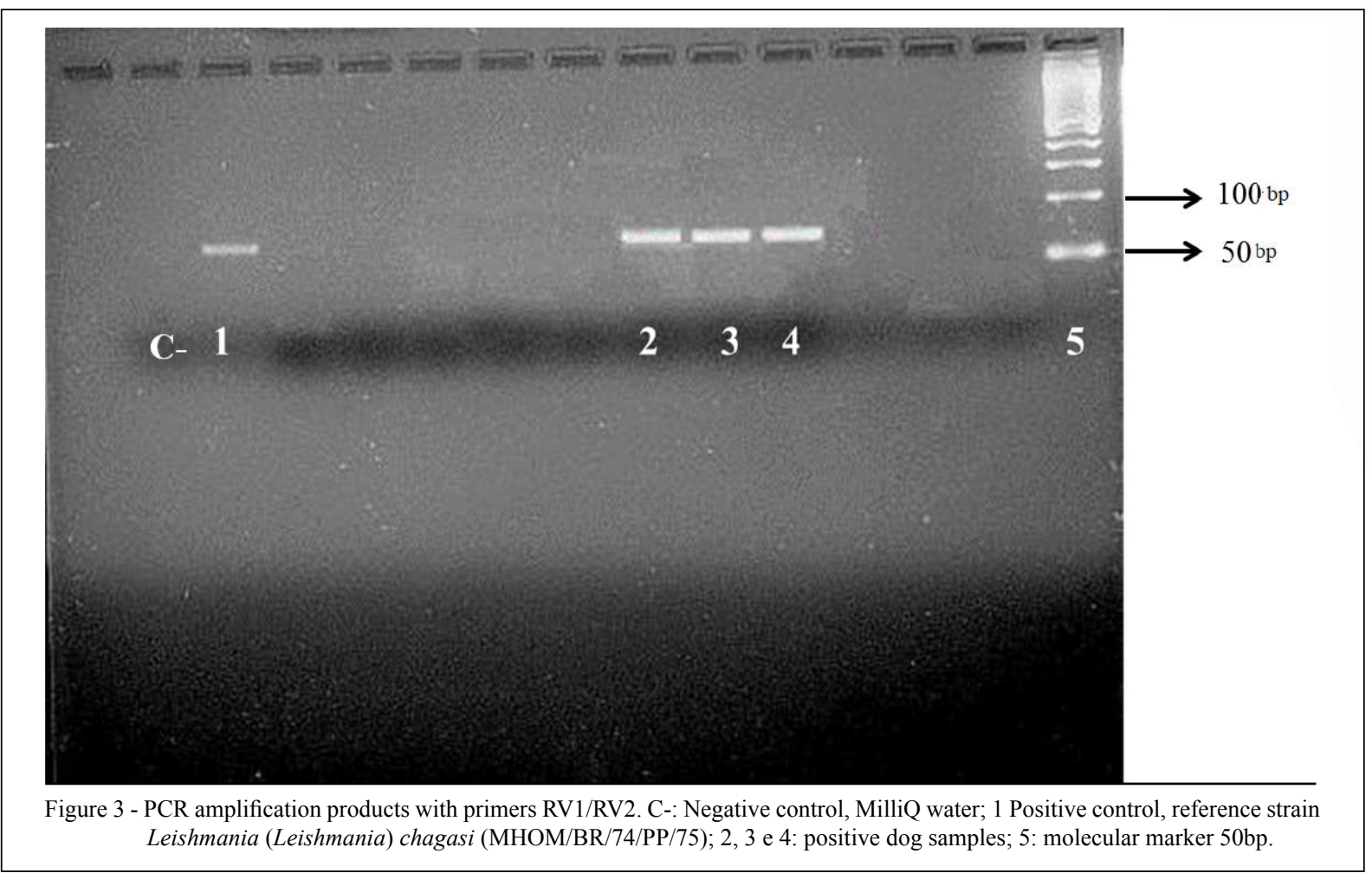

the IFAT for the confirmatory diagnosis. After some studies, and through a BHM technical note (Nota Técnica $n^{0}$ 01/2011 - CGDT/CGLAB/DEVIT/SVS/ MS), this context has been modified to $\mathrm{DPP}^{\circledR}$ for screening and ELISA for confirmatory, allowing this screening to be performed in all Brazilian municipalities (BRASIL, 2014).

However, if in our study we had adopted the strategy recommended by the $\mathrm{BMH}$, a low number of infected dogs, as confirmed by ELISA (8/92), would have escaped detection. Regarding the DPP ${ }^{\circ}$, it is considered easy to apply in field research. In the studies undertaken by GRIMALDI JÚNIOR et al. (2012), this test showed high sensitivity in symptomatic dogs. This result is corroborated in our study since all symptomatic animals were positive in this diagnostic test. The differences reported in the present study between the reactivity of the serum samples may result from false positive reactions due to cross-reactivity with agents other than Leishmania and the sensitivity thresholds of other tests (LIRA et al., 2006; SANTOS et al., 2010). However, some studies have reported no crossreactivity between Leishmania and other pathogens (OLIVEIRA et al., 2008; GUIMARÃES et al., 2009). Another possibility is that the levels of anti-
Leishmania antibodies were below the cut-off point used as positive, as shown by SILVA et al. (2009), which IFAT assay using a 1:20 dilution showed a better contingency coefficient.

The use of the Woo technique is justified, given the occurrence of Trypanosoma evansi in domestic animals at the Bodoquena Plateau, in the Pantanal of the Mato Grosso do Sul and in Bonito Municipality (STEVENS et al., 1989; NUNES et al., 1994; SAVANI et al., 2005), also present in a dog from the rural area of the São Paulo State (COELHO et al., 2013).

The isolation of the parasite by $\mathrm{NNN}$ culture has its importance for obtaining parasite "in-mass" for use of techniques such as monoclonal antibodies and biochemical characterization, as observed in studies by DE SANTIS et al. (2011).

In Águas do Miranda, the evidence of dogs carrying $L$. infantum chagasi and the presence of Lutzomyia longipalpis circulating in the peridomicile environment (BRILHANTE et al., 2015a) together with insufficient knowledge of the population about the disease, its severity and the forms of transmission, points to the possibility of introducing visceral leishmaniasis to the residents of that district, as well as for tourists, like other areas of canine cases preceding human cases of parasitosis (GONTIJO \& MELO, 2004). 


\section{CONCLUSION}

Our results showed low agreement between the serological tests recommended by the BHM, and it is necessary to associate other diagnostic techniques, such as parasitological tests and PCR, to increase the sensitivity for CVL diagnosis, mainly regarding the asymptomatic dogs in endemic areas. Although, these methods are expensive and require high professional qualification, the proposal should be discussed among Brazilian health authorities, since euthanasia of positive dogs is one of the main measures of control of VL in Brazil.

In addition, our findings may help the surveillance agencies in Bonito, because the high prevalence of seropositive dogs in this endemic region may contribute to an increase in the prevalence of infection in humans, since the municipality of Bonito is considered a moderate transmission area of leishmaniasis.

\section{ACKNOWLEDGEMENTS}

The authors thank Universidade AnhangueraUniderp for the financial support, and the Zoonosis Control Center of Bonito Municipality for the logistic support.

\section{BIOETHICS AND \\ BIOSECURITY COMMITTEE APPROVAL}

This study was approved by the Ethics Committee of Animal Use of the Universidade Anhanguera/Uniderp, Unidade Agrárias, Campo Grande, MS (authorization: 76-011/09-MS). Results of this research were sent to the Center of Zoonosis Control of Bonito Municipality, so that control measures could be taken.

\section{DECLARATION OF CONFLICTING INTERESTS}

The authors declare no conflicts of interest.

\section{REFERENCES}

AGUIAR, D.M. et al. Seroprevalence of anti-Leishmania spp. antibodies in rural dogs from the city of Monte Negro, State of Rondônia, Brazil. Revista Brasileira de Parasitologia Veterinária, v. 19, p. 73-74, 2010. Available from: < http://dx.doi. org/10.4322/rbpv.01901014>. Accessed Jul. 07, 2017.

ANDRADE, A.R.O et al. Epidemiological study on leishmaniasis in an area of environmental tourism and ecotourism, state of Mato Grosso do Sul, 2006-2007. Revista da Sociedade Brasileira de Medicina Tropical, v. 42, p. 488-493, 2009. Available from: <http://dx.doi. org/10.1590/S0037-86822009000500003>. Accessed Nov. 10, 2015.

ASSIS, J. et al. Comparative study of diagnostic methods for visceral leishmaniasis in dogs from Ilha Solteira, SP. Revista Brasileira de Parasitologia Veterinária, v. 19, p. 17-25, 2010. Available from: $<$ http://dx.doi.org/10.4322/rbpv.01901004>. Accessed Jul. 07, 2017.
AYRES, M. et al. BioEstat 5.0: aplicações estatísticas nas áreas das ciências biológicas e médicas. Belém: MCT; IDSM; CNPq, 2007. 364 p. Available from: <http://www.mamiraua.org.br/pt-br/downloads/ programas/bioestat-versao-53/>. Accessed: 01 Aug. 2017.

BONITO. Prefeitura Municipal de Bonito. Relatório de planejamento da Prefeitura Municipal de Bonito. Bonito; Mato Grosso do Sul, 2009.

BONITO. Prefeitura Municipal de Bonito. Secretaria de Indústria, Turismo e Comércio. Available from: $<$ http://www.bonito.ms.gov. br/>. Accessed: Jun. 29, 2016

BRASIL. Ministério da Saúde. Manual de Vigilância e Controle da Leishmaniose Visceral, Brasilia-DF, $1^{\mathrm{a}}$ ed. $5^{\mathrm{a}}$ reimpressão, 2014. Available from: <http://bvsms.saude.gov.br/bvs/publicacoes/ manual_vigilancia_controle_leishmaniose_visceral_1edicao.pdf $>$ Accessed: Nov. 08, 2015.

BRILHANTE, A.F. et al. Natural infection of phlebotomines (Diptera: Psychodidae) by Leishmania (Leishmania) amazonensis in an area of ecotourism in Central-Western Brazil. Journal of Venomous Animals Toxins Including Tropical Diseases, v. 31, p. 1-3, 2015b. Available from <http://dx.doi.org/10.1186/s40409015-0041-8>. Accessed: 12 Jul., 2016.

BRILHANTE, A.F. et al. Phlebotomine fauna (Diptera: Psychodidae) in an area of fishing tourism in Central-Western Brazil. Revista do Instituto de Medicina Tropical de São Paulo, v. 57, p. 233-238, 2015a. Available from: <http://dx.doi.org/10.1590/S003646652015000300009>. Accessed: Jul. 12, 2016.

COELHO, W.M.D. et al. Detection of co-infections by Leishmania (L.) chagasi, Trypanosoma evansi, Toxoplasma gondii and Neospora caninum in dogs. Ars Veterinaria, v. 29, p. 169174, 2013. Available from <http://dx.doi.org/10.15361/21750106.2013v29n3p169-174>. Accessed: Jul. 07, 2017.

CORTADA, V.M.C.L. et al. Canine visceral leishmaniasis in Anastácio, Mato Grosso do Sul State, Brazil. Veterinary Research Communications, v. 24, p. 365-374, 2004. Available from: $<\mathrm{http} / /$ dx.doi.org/10.1023/B:VERC.0000035014.80785.b7>. Accessed: Jul. 20, 2016.

COURA-VITAL, W. et al. Prevalence and factors associated with Leishmania infantum infection of dogs from an urban area of Brazil as identified by molecular methods. PLoS Neglected Tropical Diseases, v. 8, e1291, 2011. Available from: $<$ http://dx.doi. org/10.1371/journal.pntd.0001291>. Accessed: Sept. 24, 2016

DANTAS-TORRES, F. et al. Seroepidemiological survey on canine leishmaniasis among dogs from an urban area of Brazil. Veterinary Parasitology, v. 140, p. 54-60, 2006. Available from: <http://dx.doi. org/10.1016/j.vetpar.2006.03.008>. Accessed Sept. 24, 2016.

DE SANTIS, B. et al. Characterization of Leishmania infantum species in dogs from the urban area of Cuiabá, State of Mato Grosso, Brazil. Revista da Sociedade Brasileira de Medicina Tropical, v. 44, n. 6, p. 771-773, 2011. Available from: <http://dx.doi. org/10.1590/S0037-86822011000600022>. Accessed: Jul. 10, 2017.

DESANTIS, B.etal.Performance ofDPPTM immunochromathographic rapid test (IRT) for canine visceral leishmaniasis: comparison with other serological methods in suspected dogs from Cuiabá, Mato Grosso State, Brazil. Brazilian Journal of Veterinary Research and Animal Science, v. 50, p. 198-205, 2013. Available from: <http:// 
dx.doi.org/10.11606/issn.1678-4456.v50i3p198-205>. Accessed: Jul. $12,2016$.

GALATI, E.A.B. et al. Phlebotomines (Diptera: Psychodidae) in forested areas of the Serra da Bodoquena, state of Mato Grosso do Sul, Brazil. Memórias do Instituto Oswaldo Cruz, v. 101, p. 175-193, 2006. Available from: <http://dx.doi.org/10.1590/S007402762006000200010>. Accessed: Aug. 14, 2016.

GONTIJO, C.M.F.; MELO, M.N. Visceral Leishmaniasis in Brazil: current status, challenges and prospects. Revista Brasileira de Epidemiologia, v. 7, p. 338-349, 2004. Available from: < http://dx.doi. org/10.1590/S1415-790X2004000300011>. Accessed: Jul. 10, 2016.

GRIMALDI JÚNIOR, G. et al. Evaluation of a novel chromatographic immunoassay based on Dual-Path Platform technology (DPP ${ }^{\circledR}$ CVL rapid test) for the serodiagnosis of canine visceral leishmaniasis. Transactions of Royal Society and Tropical Medicine and Hygiene, v. 106, p. 54-59, 2012. Available from: <http://dx.doi.org/10.1016/j. trstmh.2011.10.001>. Accessed: Aug. 14, 2016.

GUIMARÃES, A.M. et al. Fatores associados à soropositividade para Babesia, Toxoplasma, Neospora e Leishmania em cães atendidos em nove clínicas veterinárias do município de Lavras, MG. Revista Brasileira de Parasitologia Veterinária, v. 18, p. 49-53, 2009. Available from: <http://dx.doi.org/10.4322/ rbpv.018e1009>. Accessed: Jul. 10, 2016.

IBGE - Instituto Brasileiro de Geografia e Estatística. Available from: <http://cidades.ibge.gov.br/painel/historico. php?codmun=500220>. Accessed: Jun. 21, 2016.

LAINSON, R.; SHAW, J.J. New World Leishmaniasis. In: FEG Cox, JP Kreir, D Wakelin (eds). Microbiology and Microbial Infections, Parasitology. Topley \& Wilson's, Arnold, Sydney, Auckland; p. 313-349, 2005.

LAURENTI, M.D. et al. Asymptomatic dogs are highly competent to transmit Leishmania (Leishmania) infantum chagasi to the natural vector. Veterinary Parasitology, v. 196, p. 296-300, 2013. Available from: $<$ http://dx.doi.org/10.1016/j.vetpar.2013.03.017> . Accessed: Jul. 12, 2017.

LIMA-JÚNIOR, M.S.C. et al. Identification of Leishmania species isolated in human cases in Mato Grosso do Sul, by means of the polymerase chain reaction. Revista da Sociedade Brasileira de Medicina Tropical, v. 42, p. 303-308, 2009. Available from: $<$ http://dx.doi.org/10.1590/S0037-86822009000300012>. Accessed: Sept. 02, 2016.

LIRA, R.A. et al. Canine visceral leishmaniosis: A comparative analysis of the EIE-leishmaniose visceral canina BioManguinhos and the IFI leishmaniose visceral canina BioManguinhos kits. Veterinary Parasitology, v. 137, p. 11-16, 2006. Available from: <http://dx.doi. org/10.1016/j.vetpar.2005.12.020>. Accessed: Sept. 20, 2016.

LOPES, E.G. et al. Serological and molecular diagnostic tests for canine visceral leishmaniasis in Brazilian endemic area: one out of five seronegative dogs are infected. Epidemiology and Infection, v. 20 , p. 1-9, 2017. Available from: <http://dx.doi.org/10.1017/ S0950268817001443>. Accessed: Aug. 10, 2017.

MATO GROSSO DO SUL (Estado). Secretaria de Estado de Saúde. Coordenadoria Estadual de Vigilância Epidemiológica. Informe epidemiológico das leishmanioses $n^{\circ} 1 / 2014$. Campo Grande, MS, 2014.
MISSAWA, N.A. et al. Evidence of transmission of visceral leishmaniasis by Lutzomyia cruzi in the municipality of Jaciara, State of Mato Grosso, Brazil. Revista da Sociedade Brasileira de Medicina Tropical, vol. 44, p. 76-78, 2011. Available from: <http://dx.doi.org/10.1590/S0037-86822011000100017>. Accessed 22 Aug., 2017.

MORENO, J.; ALVAR, J. Canine leishmaniasis: epidemiological risk and the experimental model. Trends in Parasitology, v. 18, p. 399-405, 2002. Available from: <http://dx.doi.org/10.1016/S14714922(02)02347-4>. Accessed: Sep. 15, 2016.

NUNES, V.L.B. et al. Study of phlebotomines (Diptera, Psychodidae) in the urban area of Bonito municipality, Mato Grosso do Sul, Brazil. Revista Brasileira de Entomologia, v. 52, p. 446-451, 2008. Available from: <http://dx.doi.org/10.1590/ S0085-56262008000300019>. Accessed: Jul. 15, 2017.

NUNES, V.L.B. et al. Estudos epidemiológicos sobre leishmaniose tegumentar (LT) e Mal das Cadeiras no município de Corguinho, Mato Grosso do Sul - Estudo de reservatórios, 1992-1994. Revista Brasileira Parasitologia Veterinária, v. 3, p. 29-35, 1994. Available from: <http://cbpv.org.br/rbpv/documentos/311994/r3129_35.pdf>. Accessed: Jul. 05, 2016.

NUNES, V.L.B. et al. Estudos epidemiológicos sobre leishmaniose visceral em cães de Corumbá, Mato Grosso do Sul. Pesquisa Veterinária Brasileira, v. 8, p. 17-21, 1988.

NUNES, V.L.B. et al. Occurrence of canine visceral leishmaniasis in an agricultural settlement in the State of Mato Grosso do Sul, Brazil. Revista da Sociedade Brasileira de Medicina Tropical, v. 34, p. 301-302, 2001. Available from: <http://dx.doi.org/10.1590/ S0037-86822001000300014>. Accessed: Jul. 05, 2016.

OLIVEIRA, A.L.L. et al. Emergent outbreak of visceral leishmaniasis in Mato Grosso do Sul State. Revista da Sociedade Brasileira de Medicina Tropical, v. 39, p. 446-450, 2006. Available from: <https://dx.doi. org/10.1590/S0037-86822006000500005>. Accessed: Jul. 30, 2017.

OLIVEIRA, T.M.F.S. et al. A study of cross-reactivity in serum samples from dogs positive for Leishmania sp., Babesia canis and Ehrlichia canis in enzyme-linked immunosorbent assay and indirect fluorescent antibody test. Revista Brasileira de Parasitologia Veterinária, v. 17, p. 7-11, 2008. Available from: <http://dx.doi. org/10.1590/S1984-29612008000100002>. Accessed: Jul. 30, 2017.

QUEIROZ, N.M.G.P. et al. Canine Visceral Leishmaniasis diagnosis by immunohistochemistry and PCR in skin tissues in association with RIFI and ELISA-test. Revista Brasileira de Parasitologia Veterinária, v. 19, p. 32-38, 2010. Available from <http://dx.doi. org/10.4322/rbpv.01901006>. Accessed: Jul. 30, 2017.

SANTOS, J.M.L. et al. Prevalence of anti-Leishmania spp antibodies in dogs from Garanhuns, in the middle scrub zone (Agreste) of Pernambuco. Revista da Sociedade Brasileira de Medicina Tropical, v. 43, p. 41-45, 2010. Available from: <http://dx.doi. org/10.1590/S0037-86822010000100010>. Accessed Aug. 12, 2016.

SANTOS, S.O. et al. Incrimination of Lutzomyia cruzi as a vector of American Visceral Leishmaniasis. Medical and Veterinary Entomology, v. 12, p. 315-317, 1998. Available from: <http://dx.doi. org/10.1046/j.1365-2915.1998.00104.x>. Accessed: Jul. 30, 2017.

SAVANI, E.S.M.M. et al. Occurrence of co-infection by Leishmania (Leishmania) chagasi and Trypanosoma (Trypanozoon) evansi in a 
dog in the state of Mato Grosso do Sul, Brazil. Memórias do Instituto Oswaldo Cruz, v. 100, p. 739-741, 2005. Available from: <http:// dx.doi.org/10.1590/S0074-02762005000700011>. Accessed: Aug. 14,2016

SAVANI, E.S.M.M. et al. The finding of Lutzomyia almerioi and Lutzomyia longipalpis naturally infected by Leishmania spp in a cutaneous and canine visceral leishmaniases focus in serra da Bodoquena, Brazil. Veterinary Parasitology, v. 160, p. 18-24, 2009. Available from: <https://doi.org/10.1016/j. vetpar.2008.10.090>. Accessed: Aug. 14, 2016

SILVA, R.M. et al. TG-ROC analysis of immunofluorescence assays in canine visceral leishmaniasis diagnosis. Revista de Saúde Pública, v. 43, p. 1-9, 2009. Available from: $<$ http://dx.doi.org/10.1590/S003489102009005000063>. Accessed: Oct. 02, 2016.

SOLANO-GALLEGO, L. et al. Serological diagnosis of canine leishmaniosis: comparison of three commercial ELISA tests (Leiscan ${ }^{\circledR}$, ID Screen ${ }^{\circledR}$ and Leishmania $96^{\circledR}$ ), a rapid test (Speed Leish $\mathrm{K}()$ and an in-house IFAT. Parasites \& Vectors, v. 7, p. 1-10, 2014. Available from $<$ http://dx.doi.org/10.1186/1756-33057-111>. Accessed: Aug. 10, 2017.

STEVENS, J.R. et al. Isoenzyme characterization of Trypanosoma evansi isolated from capybaras and dogs in Brazil. Acta Tropica, v. 46, p. 213-222, 1989. Available from: <https://projects.exeter. ac.uk $/ \mathrm{meeg} / \mathrm{sites} / \mathrm{default} /$ files/publications/Stevens $\% 20 \mathrm{et} \% 20$ al\%201989\%20Acta\%20Tropica.pdf>. Accessed: Jul. 05, 2016.

TÁVORA, M.P.F. et al. Comparative validation study between the ELISA and RIFI techniques for diagnosing Leishmania sp in stray dogs caught in the municipality of Campos de Goytacazes, State of Rio de Janeiro. Revista da Sociedade Brasileira de Medicina Tropical, v. 40, p. 482-483, 2007. Available from: <http://dx.doi. org/10.1590/S0037-86822007000400023>. Accessed: Jul. 15, 2017.

VERCOSA, B.L, et al. Transmission potential, skin inflammatory response, and parasitism of symptomatic and asymptomatic dogs with visceral leishmaniasis. BMC Veterinary Research, v. 4, p 45, 2008. Available from: <https://dx.doi.org/10.1186/1746-61484-45>. Accessed: Jul. 15, 2017.

WOO, P.T.K. The haematocrit centrifuge technique for the detection of Trypanosomes in blood. Canadian Journal of Zoology, v. 47, p. 921-923, 1969. Available from <https://dx.doi. org/10.1139/z69-150>. Accessed: Jul. 10, 2017.

YAMAMOTO, Y.Y. et al. Estudo da eficiência das reações de imunofluorescência e de hemaglutinação passiva no diagnóstico de leishmaniose visceral em cães. Revista da Faculdade de Medicina Veterinária e Zootecnica da Universidade de São Paulo, v. 25, p. 143-152, 1988. Available from <http://dx.doi.org/10.11606/ issn.2318-3659.v25i1p143-152>. Accessed: Jul. 10, 2017. 